\title{
Influence of Neonicotinoids on Selected Characteristics of the Earthworm Dendrobaena Veneta (Rosa) in Laboratory Conditions
}

\author{
Mariola Garczyńska1*, Grzegorz Pączka', Joanna Kostecka' \\ 1 Department of Natural Theories of Agriculture and Environmental Education, Faculty of Biology and \\ Agriculture, University of Rzeszów, 35-601 Rzeszów, Ćwiklińskiej 1A str., Poland \\ * Corresponding author's e-mail:mgar@ur.edu.pl
}

\begin{abstract}
In the laboratory experiment, the effect of neonicotinoid Nuprid 200SC at the dose recommended by the manufacturer on the dynamics of population of earthworms Dendrobaena veneta was assessed. The studies were conducted on mature $D$. veneta specimens, in 4 replications of beddings (control, insecticide) in the climatic chamber. Condition of the population was checked five times, using a method of manual segregation of beddings. Insecticide limited the increase in number and biomass of $D$. veneta population (both the whole population, mature specimens and immature earthworms), but also restricted its reproduction (it decreased the number of cocoons laid by earthworms $(\mathrm{p}<0.05))$.
\end{abstract}

Keywords: ecotoxicology, Dendrobena veneta Rosa, imidacloprid Nuprid 200 SC

\section{INTRODUCTION}

Nowadays, neonicotinoids (NEO) are the most well-known group of insecticides in the world and they constitute approximately $25 \%$ of the global insecticide market, while they are mainly applied as an additive to seed treatments (Renaud et al. 2018). They are used in 120 countries to control agricultural pests, mainly due to a wide spectrum of their application. Most of these insecticides were marketed in 1995-2002 (Hladik et al. 2018). They affect the central nervous system of target organisms (whiteflies, aphids, some microlepidoptera), but also the so-called nontarget organisms (e.g. pollinators) (Bonmatin et al. 2014; Hladik et al. 2018; Rayman et al. 2018). Up to now, many papers have been focused on the effect of neonicotinoids on bees, however, there has been more evidence indicating that low neonicotinoid level persisting in soil environment has a negative effect on other organisms (Wang et al. 2015 a,b; Eng et al. 2017; Wood \& Goulson 2017).

Botías et al. (2016) demonstrated that the remnants of these compounds in soil were discovered more than three years after the application of seed treatments in agricultural crops. Thus, they should be applied carefully and in the situations when there are no other possibilities (Hladik et al. 2018).

The influence of xenobiotics on earthworm populations, even at low doses recommended by the manufacturers as safe, can be very different (Alves et al. 2013; Uhl et al. 2015; Garczyńska et al. 2018). In relation to this, there is a need for a broader assessment of the effect of NEO on soil fauna under varying environmental conditions.

The aim of the present study was to assess the effect of the neonicotinoid Nuprid 200 SC (at the dose described by the manufacturer as safe) on the characteristics of the population of Dendrobaena veneta earthworms Rosa 1893.

\section{MATERIAL AND METHODS}

\section{Earthworms- test organisms}

Earthworms (Oligochaeta; Lumbricidae) Dendrobaena veneta (Rosa 1893) (Figs 1, 2) originating from the conservative breeding in the Department of Biological Basis of 


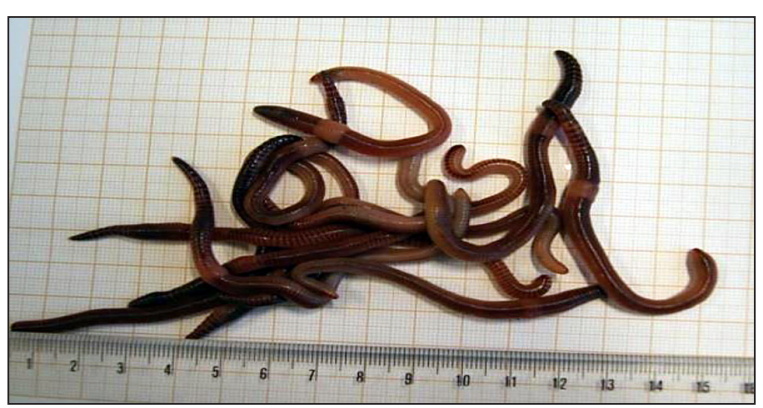

Fig. 1. Mature D. veneta earthworms

Agriculture and Environmental Education of the University of Rzeszów, Poland, were used in the experiment. Specimens that had been subjected to prior acclimation in garden soil were tested.

\section{Applied formulation}

Nuprid 200SC (Nufarm Polska sp. z o.o.) is an insecticide belonging to the neonicotinoid group whose active substance is imidacloprid (17.8\%): 1-[(6-chloro-3-pyridynyl)methyl]-Nnitro-2-imidazolidinoamine. The formulation was applied once, at the dose recommended by the manufacturer (as the equivalent of the concentration of $\left.0.4 \mathrm{ml} \cdot \mathrm{m}^{-2}\right)$.

\section{Course of the experiment}

The studies were carried out on a balanced biomass of mature $D$. veneta specimens. Ten earthworm specimens were placed into each plastic container (of size of $20 \times 15 \times 10 \mathrm{~cm}$ ) filled with garden soil (Table 1). In order to restrict the number of enchytraeids competing with earthworms, vermicomposted kitchen waste were mixed with cellulose (in 2:1 ratio) (Kostecka 2000). The waste was provided regularly, according to the needs of the bred earthworms, and were put into large-size nylon mesh (mesh size: $5 \mathrm{~mm}$ ).

The experiment was conducted from March to August 2017 in the climatic chamber $\left(20 \pm 0.5^{\circ} \mathrm{C}, 24 \mathrm{~L}\right.$; with soil humidity of approximately $70 \%$ ) (OECD 2004). The condition of earthworm population was checked regularly, once a month, using a method of manual segregation of beddings (e.g. Pelosi et al. 2009).

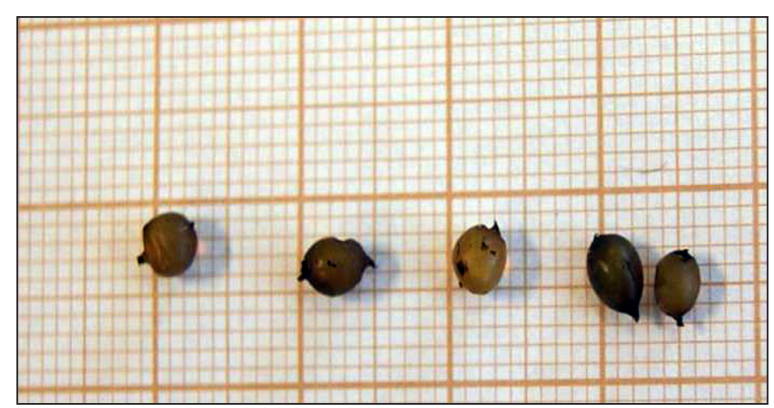

Fig. 2. Cocoons laid by $D$. veneta

\section{Statistical analysis}

The obtained results were presented as arithmetic means and standard deviations. STATISTICA software v. 13.1 (StatSoft) was used for statistical calculations. Normal distribution was checked using Shapiro-Wilk $W$ test and BrownForsythe test was used to confirm the homogeneity of variance. To find significant differences between the data related to parameters of populations, the two-way ANOVA with the LSD test (post-hoc) were subjected (Stanisz 2006). Differences at the significance level $\alpha=0.05$ were considered statistically significant.

\section{RESULTS}

\section{The effect of insecticide Nuprid 200SC on D. veneta earthworms}

\section{The effect of insecticide on the number of earthworms}

The applied formulation had a negative effect on the number of earthworm populations $(F=94.183$, $p<0.01)$. Starting from the second month of the experiment, neonicotinoid reduced the number of population $(\mathrm{H}=8.918 ; \mathrm{p}<0.05)$ (Table 2$)$.

The insecticide caused a reduction in the mean number of mature earthworms $(F=78.460$, $p<0.0001$ ) (Fig. 3) and immature specimens $(F=63.370, p<0.001)$ (Fig. 4).

\section{The effect of insecticide on the biomass of earthworms}

Biomass of the earthworm population treated with insecticide was significantly lower compared to the control $(F=178.918, \mathrm{p}<0.0001)$ (Table 3$)$ and the applied agent reduced the mean weight of an individual specimen $(\mathrm{F}=1.034, \mathrm{p}<0.05)$ (Table 4). 
Table 1. Schematic diagram of the experiment

\begin{tabular}{|c|c|c|c|}
\hline Containers & Bedding & D. veneta earthworms & Vermicomposted waste \\
\hline $\begin{array}{c}1-4 \\
\text { control }\end{array}$ & \multirow{2}{*}{$\begin{array}{c}1.5 \mathrm{dm}^{3} \text { of garden soil } \\
\text { each }^{* *}\end{array}$} & \multirow{2}{*}{$\begin{array}{c}10 \text { specimens to each container }{ }^{* * *} \\
(7.52 \pm 0.04)\end{array}$} & \multirow{2}{*}{$\begin{array}{l}600 \mathrm{ml} \text { of kitchen waste }{ }^{\star * \star *} \text { mixed with } 300 \\
\mathrm{ml} \text { of cellulose administered } 5 \text { times each }\end{array}$} \\
\hline $\begin{array}{c}5-8 \\
\text { formulation* }\end{array}$ & & & \\
\hline
\end{tabular}

* Nuprid 200SC formulation at the equivalent of dose of $0.4 \mathrm{ml} \cdot \mathrm{m}^{-2}$ - according to manufacturer's recommendations

** Kronen universal soil: $\mathrm{pH}$ in $\mathrm{H}_{2} \mathrm{O} 6.0-6.5$; salinity $1.0-2.0 \mathrm{mg} \cdot \mathrm{dm}^{-3} ; \mathrm{N} 200-450 \mathrm{mg} \cdot \mathrm{dm}^{-3} ; \mathrm{P}_{2} \mathrm{O}_{5} 200-400 \mathrm{mg} \cdot \mathrm{dm}^{-3}$;

$\mathrm{K}_{2} \mathrm{O} 300-500 \mathrm{mg} \cdot \mathrm{dm}^{-3}$; solid, loose form, fraction 0-20 mm

*** With known and balanced biomass within each container

**** Leftovers composed of pasta, bread, apple and potato peelings in the ratio of 1:1:1:1

Table 2. Mean number of $E$. fetida individuals (ind $\cdot{ }^{-}$container ${ }^{-1} \pm \mathrm{SD}$ ) in experimetal boxes depending on the presence of preparation during 5 months experiment

\begin{tabular}{|c|c|c|c|c|c|c|}
\hline Time & Start of the experiment & 1st month & 2nd month & 3rd month & 4th month & 5 th month \\
\hline Control & $10.0 \pm 0.0$ & $60 \pm 1.4^{\mathrm{a}}$ & $94 \pm 1.3^{\mathrm{a}}$ & $103 \pm 4.2^{\mathrm{a}}$ & $125 \pm 3.8^{\mathrm{a}}$ & $148 \pm 2.2^{\mathrm{a}}$ \\
\hline Nuprid 200SC & $10.0 \pm 0.0$ & $71 \pm 0.9^{\mathrm{a}}$ & $65 \pm 1.9^{\mathrm{b}}$ & $26 \pm 0.5^{\mathrm{b}}$ & $9 \pm 3.0^{\mathrm{b}}$ & $2 \pm 1.0^{\mathrm{b}}$ \\
\hline
\end{tabular}

a, b- significant differences.

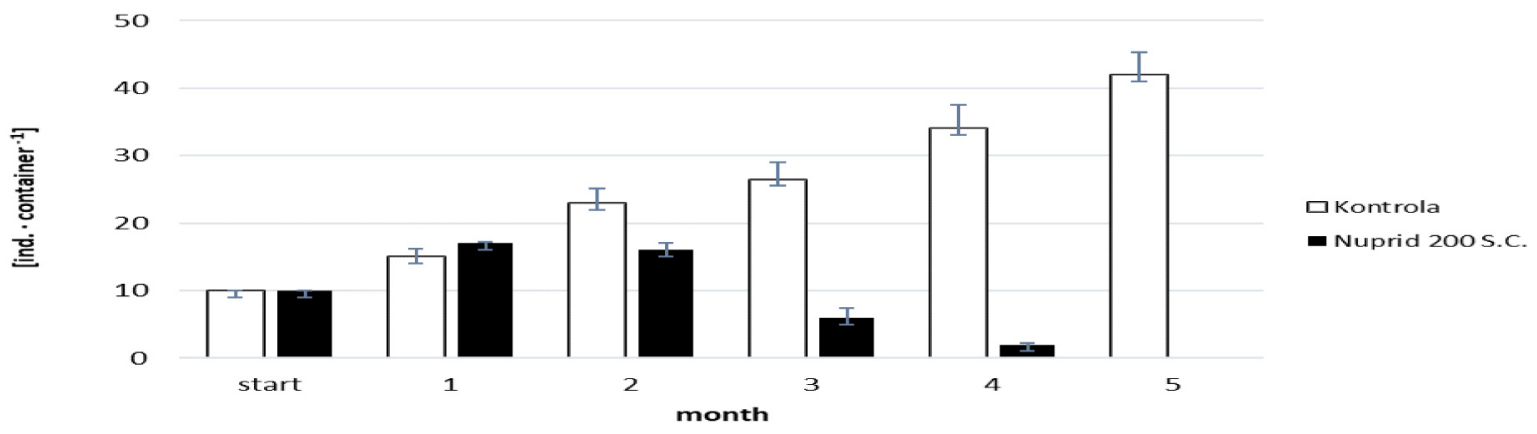

Fig. 3. Effects of the xenobiotic Nuprid $200 \mathrm{SC}$ on mean number of mature indivduals [ind. cont $^{-1}$ ]

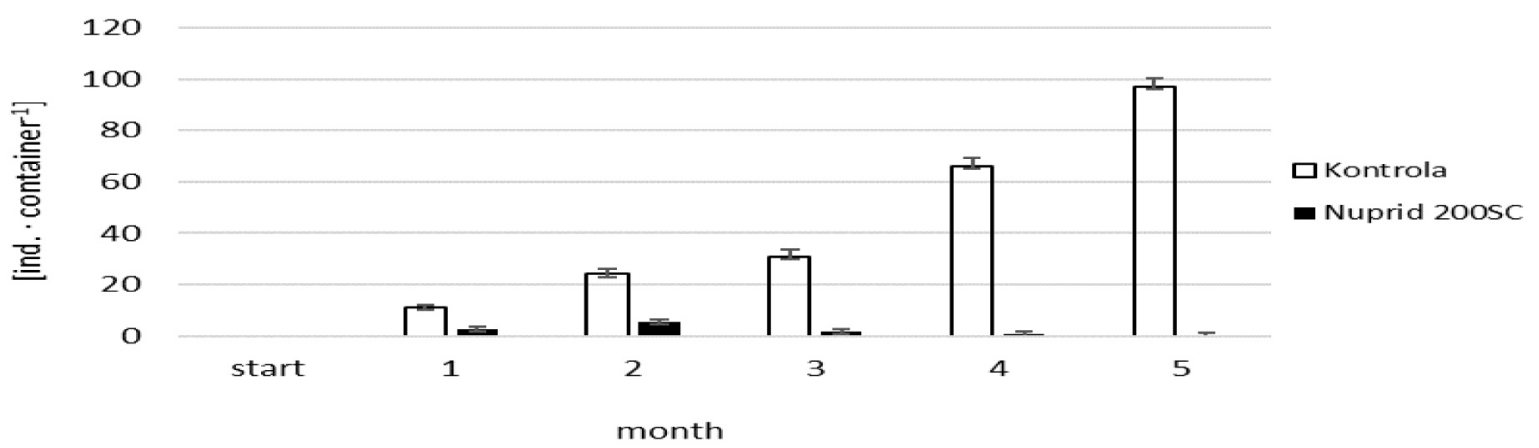

Fig. 4. Effects of the xenobiotic Nuprid $200 \mathrm{SC}$ on mean number of immature indivduals [ind. $\cdot \operatorname{cont}^{-1}$ ]

Nuprid 200 SC reduced the biomass of reproducing specimens. It was gradually decreased - in July by $82 \%$, and in August by $94 \%$ $(\mathrm{p}<0.0001)$ (Table 5). Insecticide also negatively affected the weight of an individual mature specimen $(p<0.01)$ (Table 6).

Biomass of young specimens and the weight of individual young specimens were reduced by the insecticide as well $(\mathrm{F}=1.024, \mathrm{p}<0.01)$ (Table 7).

\section{The effect of insecticide on the reproduction of $D$. veneta earthworms}

Insecticide Nuprid 200SC administered at the environmentally safe dose significantly modified the number and biomass of cocoons laid by $D$. veneta. The life strategy of $D$. veneta in the control group consisted in assigning the whole energy for reproduction. However, a decrease in the number of cocoons after the contact with Nuprid 
Table 3. Mean biomass of D.veneta (specimens) ( $g \cdot$ container $\left.^{-1} \pm \mathrm{SD}\right)$ in experimental boxes depending on the presence of preparation during 5 months experiment

\begin{tabular}{|c|c|c|c|c|c|c|}
\hline Time & $\begin{array}{c}\text { Start of the } \\
\text { experiment }\end{array}$ & 1st month & 2nd month & 3rd month & 4th month & 5th month \\
\hline Control & $5.5 \pm 0.1$ & $18.1 \pm 0.8^{\mathrm{a}}$ & $38.6 \pm 6.5^{\mathrm{a}}$ & $48.7 \pm 0.1^{\mathrm{a}}$ & $80.2 \pm 0.4^{\mathrm{a}}$ & $85.8 \pm 0.8^{\mathrm{a}}$ \\
\hline Nuprid 200SC & $5.7 \pm 0.2$ & $13.8 \pm 0.9^{\mathrm{a}}$ & $17.8 \pm 6.5^{\mathrm{b}}$ & $6.7 \pm 0.1^{\mathrm{b}}$ & $2.5 \pm 0.0^{\mathrm{b}}$ & $1.43 \pm 0.0^{\mathrm{b}}$ \\
\hline
\end{tabular}

$\mathrm{a}, \mathrm{b}$ - significant differences

Table 4. Mean mass of D.veneta specimens $\left(\mathrm{g} \cdot\right.$ container $\left.^{-1} \pm \mathrm{SD}\right)$ in experimental boxes depending on the presence of preparation during 5 months experiment

\begin{tabular}{|c|c|c|c|c|c|c|}
\hline Time & $\begin{array}{c}\text { Start of the } \\
\text { experiment }\end{array}$ & 1st month & 2nd month & 3rd month & 4th month & 5th month \\
\hline Control & $0.478 \pm 0.1$ & $0.424 \pm 0.8^{\mathrm{a}}$ & $0.385 \pm 0.5^{\mathrm{a}}$ & $0.378 \pm 0.1^{\mathrm{a}}$ & $0.345 \pm 0.4^{\mathrm{a}}$ & $0.323 \pm 0.2^{\mathrm{a}}$ \\
\hline Nuprid 200SC & $0.527 \pm 0.2$ & $0.474 \pm 0.9^{\mathrm{a}}$ & $0.365 \pm 0.5^{\mathrm{a}}$ & $0.342 \pm 0.1^{\mathrm{b}}$ & $0.273 \pm 0.0^{\mathrm{b}}$ & $0.267 \pm 0.0^{\mathrm{b}}$ \\
\hline
\end{tabular}

$\mathrm{a}, \mathrm{b}$ - significant differences

Table 5. Mean biomass of adult of D.veneta $\left(\mathrm{g} \cdot\right.$ container $\left.^{-1} \pm \mathrm{SD}\right)$ depending on the presence Nuprid 200SC during 5 months experiment

\begin{tabular}{|c|c|c|c|c|c|c|}
\hline Time & $\begin{array}{c}\text { Start of the } \\
\text { experiment }\end{array}$ & 1st month & 2nd month & 3rd month & 4th month & 5th month \\
\hline Control & $5.5 \pm 0.1$ & $8.1 \pm 1.8^{\mathrm{a}}$ & $13.3 \pm 2.5^{\mathrm{a}}$ & $13.7 \pm 2.1^{\mathrm{a}}$ & $15.2 \pm 2.4^{\mathrm{a}}$ & $16.8 \pm 2.8^{\mathrm{a}}$ \\
\hline Nuprid 200SC & $5.7 \pm 0.2$ & $9.2 \pm 1.9^{\mathrm{a}}$ & $7.8 \pm 1.5^{\mathrm{b}}$ & $2.7 \pm 0.1^{\mathrm{b}}$ & $1.2 \pm 0.0^{\mathrm{b}}$ & $0.53 \pm 0.0^{\mathrm{b}}$ \\
\hline
\end{tabular}

$\mathrm{a}, \mathrm{b}$ - significant differences

Table 6. Mean mass of adult D.veneta $\left(\mathrm{g} \cdot\right.$ container-1 $\left.^{-1} \pm \mathrm{SD}\right)$ in experimental boxes depending on the presence of preparation during 5 months experiment

\begin{tabular}{|c|c|c|c|c|c|c|}
\hline Time & $\begin{array}{c}\text { Start of the } \\
\text { experiment }\end{array}$ & 1st month & 2nd month & 3rd month & 4th month & 5th month \\
\hline Control & $0.55 \pm 0.05$ & $0.55 \pm 0.10$ & $055 \pm 0.03$ & $0.52 \pm 0.06^{\mathrm{a}}$ & $0.50 \pm 0.06^{\mathrm{a}}$ & $0.51 \pm 0.05^{\mathrm{a}}$ \\
\hline Nuprid 200SC & $0.51 \pm 0.01$ & $0.52 \pm 0.18$ & $0.42 \pm 0.05$ & $0.37 \pm 0.03^{\mathrm{b}}$ & $0.36 \pm 0.07^{\mathrm{b}}$ & $0.33 \pm 0.07^{\mathrm{b}}$ \\
\hline
\end{tabular}

a, b- significant differences

Table 7. The effect of imidaclopride on biomass of immature and the individual weight of young $D$. veneta earthworms

\begin{tabular}{|c|c|c|c|c|c|c|}
\hline \multicolumn{7}{|c|}{ Biomass ( $g \cdot$ container $^{-1} \pm S D$ ) $p<0.01$} \\
\hline $\begin{array}{c}\text { Time } \\
\text { (month) }\end{array}$ & start & 1. * & 2. * & 3. * & 4. ${ }^{*}$ & 5. * \\
\hline control & - & $8.1 \pm 0.2$ & $10.0 \pm 4.0$ & $23.3 \pm 3.5$ & $45.1 \pm 17.7$ & $69.0 \pm 21.1^{\mathrm{a}}$ \\
\hline $\begin{array}{l}\text { Nuprid } \\
\text { 200SC }\end{array}$ & - & $5.2 \pm 0.1$ & $4.2 \pm 4.5$ & $3.7 \pm 1.5$ & $1.3 \pm 1.0$ & $0.9 \pm 1,0^{b}$ \\
\hline \multicolumn{7}{|c|}{ Individual mass of young earthworms $\left(g^{\cdot}\right.$ container $\left.^{-1} \pm S D\right) p<0.01$} \\
\hline control & - & $\begin{array}{c}0.091 \\
\pm 0.009\end{array}$ & $\begin{array}{c}0.142 \\
\pm 0.002\end{array}$ & $\begin{array}{c}0.158 \pm \\
0.108\end{array}$ & $\begin{array}{c}0.158 \\
\pm 0.100\end{array}$ & $\begin{array}{c}0.183 \\
\pm 0,112^{\mathrm{a}}\end{array}$ \\
\hline $\begin{array}{l}\text { Nuprid } \\
200 S C\end{array}$ & - & $\begin{array}{c}0.117 \\
\pm 0.069\end{array}$ & $\begin{array}{c}0.063 \\
\pm 0.013\end{array}$ & $\begin{array}{c}0.096 \\
\pm 0.039\end{array}$ & $\begin{array}{c}0.085 \\
\pm 0.039\end{array}$ & $\begin{array}{c}0.057 \\
\pm 0.050^{\mathrm{b}}\end{array}$ \\
\hline
\end{tabular}

*- after sevral months, a, b - significant differences

Table 8. Mean cocoon production (cocoons $\cdot$ mature ind ${ }^{-1} \pm \mathrm{SD}$ ) of D.veneta mature individual depending on the presence Nuprid 200SC during 5 months experiment

\begin{tabular}{|c|c|c|c|c|c|c|c|}
\hline Time & $\begin{array}{c}\text { Start of the } \\
\text { experiment }\end{array}$ & 1st month & 2nd month & 3rd month & 4th month & 5th month & Mean \\
\hline Control & $0.0 \pm 0.0$ & $3.9 \pm 0.4^{\mathrm{a}}$ & $4.5 \pm 1.0^{\mathrm{a}}$ & $3.8 \pm 2,2^{\mathrm{a}}$ & $3,7 \pm 1,6^{\mathrm{a}}$ & $2,5 \pm 1,9^{\mathrm{a}}$ & $3.0 \pm 1.6^{\mathrm{a}}$ \\
\hline Nuprid 200SC & $0.0 \pm 0.0$ & $2.3 \pm 0.1^{\mathrm{a}}$ & $3.2 \pm 0.1^{\mathrm{b}}$ & $2.1 \pm 1.5^{\mathrm{b}}$ & $2,8 \pm 1.2^{\mathrm{b}}$ & $0.8 \pm 0.0^{\mathrm{b}}$ & $1.3 \pm 0.5^{\mathrm{b}}$ \\
\hline
\end{tabular}

$\mathrm{a}, \mathrm{b}$ - significant differences 


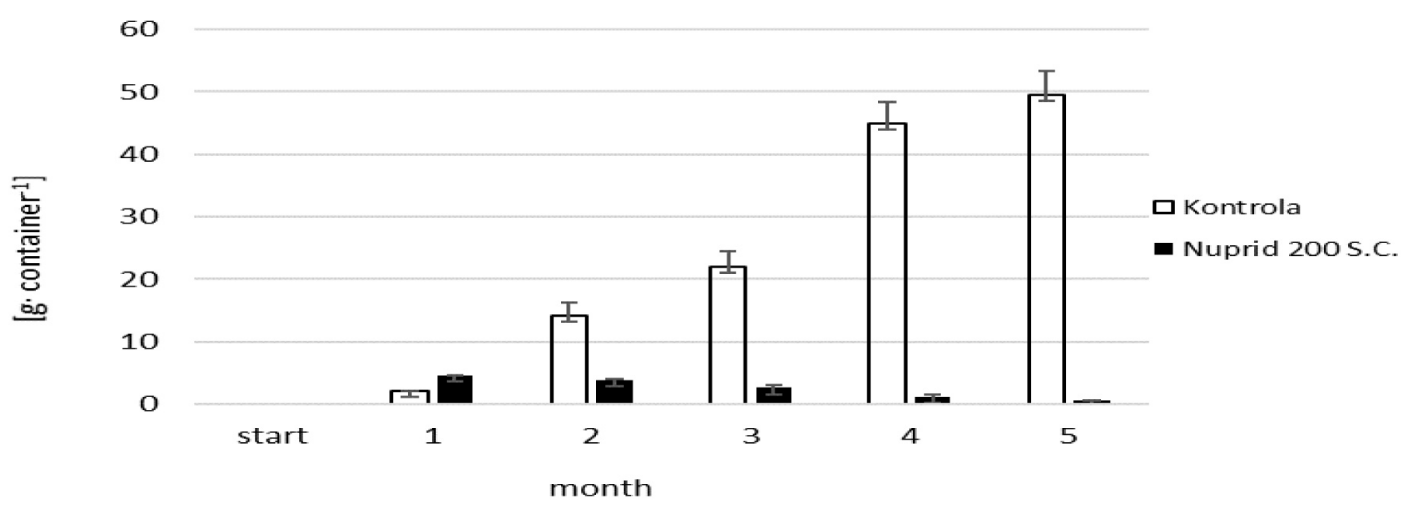

Fig. 5. Effect of the insecticide Nuprid $200 \mathrm{SC}$ on biomass of cocoons laid by earthworms $\left[\mathrm{g} \cdot \mathrm{cont}^{-1}\right.$ ]

$200 \mathrm{SC}$ amounted to (from July to August) from $66 \%$ to $98 \%(\mathrm{~F}=2.8023 ; \mathrm{p}<0.01)$.

The number of cocoons produced by an individual mature earthworm was significantly higher in the control group $(\mathrm{F}=2.063 ; \mathrm{p}<0.05)$ (Table 8).

The presence of the insecticide limited the biomass of cocoons laid by $D$. veneta as well $(\mathrm{F}=3.9043, \mathrm{p}<0.05)$ (Fig. 5).

\section{DISCUSSION}

Neonicotinoid insecticides are effective agents and thus they are competing with traditional insecticides. However, in order to obtain comprehensive and reliable results concerning toxicological risk arising from their application, it should be attempted to assess their effect on organisms, not only in the artificial soil test, but also in the natural environment and various soil types, what may be a complex study (Zhang et al. 2014; Mörtl et al. 2016). In the natural soil, unexpected synergistic and antagonistic reactions of neonicotinoids with other xenobiotics also have a significant effect on organisms. Up to now, little is known on the subject of potential toxicity of a mixture of neonicotinoids towards organisms in the environment as well (Hladik et al. 2018). Using insecticides in seed treatments may lead to their prolonged persistence in soil, which means that the non-target organisms, such as earthworms, may be exposed to them for a long time. Chronic exposure of soil organisms to xenobiotics poses a risk that is not assessed in the majority of toxicity studies (Basley \& Goulson 2017). Meanwhile, it is known that earthworm reaction depends on the duration of their exposition to these agents, the dose and age of the animals as well as sensitiveness of the species (depending on the ecomorphological group it belongs to) (Gomez-Eyles et al. 2009; Wang et al. 2015a; Basley \& Goulson 2017; Eng et al. 2017; Zhang et al. 2017; Hladik et al. 2018). Ecotoxicological studies, according to the recommendations of ISO and OECD mainly concern the epigeic species E. fetida, which has a short reproductive cycle and is relatively easy to breed (OECD 2004; Zhang et al. 2014; Wang et al. 2015a). According to Lukkari et al. (2005), $E$. fetida has greater tolerance to xenobiotics than the other species, so it would be indicated to apply stenotopic (with a narrow tolerance range) earthworms from three ecological groups, e.g. epigeic species - Dendrobena octaedra, endogeic species Aporrectodea caliginosa or anecic species Lumbricus terrestris in ecotoxicological studies.

In the present paper, studies on the effect of imidacloprid (in the form of a formulation with trade name Nuprid 200 S.C.) on D. veneta species, which is more sensitive to the effect of xenobiotics than E. fetida, were conducted (Podolak-Machowska 2016). Administration of a single dose recommended by the manufacturer had a negative effect. A decrease in the number of all the analysed age groups and cocoons was observed. In the presence of Nuprid 200 SC, health condition of mature specimens decreased and due to this, earthworms laid cocoons only during two months following the application of the agent, whereas starting from the third month, they gradually transformed the energy obtained from food into growth. Raymann et al. (2018) claim that after the exposure to imidacloprid, earthworms become less active and feed on less intensively. This is confirmed by the observations from the present experiment. According to Eng et al. (2017), after the addition of imidacloprid, maturation of earthworms is delayed by approximately 3 weeks.

It was demonstrated (Johnston et al. 2014) that earthworms exposed to a chemical stressor are able 
to modify their energy management and decrease or increase (depending on the physiological condition) the energy expenditure on detoxication. This should result in greater chances of survival in difficult conditions, but at the same time, e.g. restricts cocoon production. Sometimes a reverse situation occurs and the organisms allocate the excess energy to the production of biomass or cocoons. They may also show mixed strategies; e.g. at first, they spend a lot of energy on detoxication and then they allocate it to the production of, e.g. biomass. Garczyńska et al. (2018) have already conducted a study on the effect of acetamiprid (trade name of the formulation: $A c$ tara $25 \mathrm{WG}$ ), administered at the dose recommended by the manufacturer, on $D$. veneta earthworms. The applied insecticide did not have a negative effect on the number and biomass of the population of the studied earthworms ( $p>0.05$ ), and positively modified the number of mature $D$. veneta specimens. More of them were present in the containers with the xenobiotic $(\mathrm{p}<0.05)$. The applied xenobiotic did not affect cocoon laying by $D$. veneta.

Surely, a negative reaction of soil organisms to imidacloprid is associated with its long decomposition period in the soil ecosystem (from several months up to several years (40-997 days), which is affected by, among others, soil type) (Hladik et al. 2018). The studies demonstrated that neonicotinoid metabolites show similar toxicity to the parent compound, so their degradation does not decrease their toxicity (Suchail et al. 2004).

A high toxicity of imidacloprid towards the other earthworm $-E$. fetida was confirmed by Chen at al. (2014). When studying the effect of imidacloprid, chlorpyrifos and butachlor in the artificial soil test, the above-mentioned author observed the highest toxicity in case of the first xenobiotic. Its $\mathrm{LC}_{50}$ amounted to $3.15 \mathrm{mg} \cdot \mathrm{kg}^{-1}$ (after 7 days) and $2.82 \mathrm{mg} \cdot \mathrm{kg}^{-1}$ (after 14 days). The other two agents applied in the experiment were less toxic towards E. fetida. For example, in case of chlorpyrifos $\mathrm{LC}_{50}$ amounted to $421.39 \mathrm{mg} \cdot \mathrm{kg}^{-1}$ (after 1 week) and $384.9 \mathrm{mg} \cdot \mathrm{kg}^{-1}$ (after 2 weeks), whereas for butachlor it was $1709.79 \mathrm{mg} \cdot \mathrm{kg}^{-1}$ and 1197.8 $\mathrm{mg} \cdot \mathrm{kg}^{-1}$, respectively.

Basley \& Goulson (2017) investigated the effect of the other neonicotinoid - clothianidin (at the doses of $20 \mathrm{ppb}$ and $100 \mathrm{ppb}$, respectively) on the number of earthworms Lumbricus terrestris (deepburrowing, anecic earthworms) for the period of 4 months. Those authors conducted 3 experiments; in the first one only soil served as bedding, in the second one manure was added to the soil and in the third one, the processed food was used as bedding. The greatest decrease in the number of earthworms was observed in pure soil. Additionally, the authors found that the presence of clothianidin in the bedding for the first two months had the effect on weaker food intake by L. terrestis. A similar situation in the natural environment may cause a decrease in the decomposition rate of leaves treated with insecticides. The effect may be stronger if the earthworms come closer to the seeds treated with neonicotinoids.

Investigating the changes in body weight of earthworms under the effect of a stress factor e.g. insecticide, is a very good method to assess the influence of the said agent on the populations of these animals (Olvera-Velona et al. 2008). Dittbrenner et al. (2011) carried out an experiment in which they studied the effect of imidacloprid on body weight of E. fetida. The most pronounced decrease (by $37 \%$ ) was noted after 7 days of the experiment, in the contact with the dose of $2.0 \mathrm{mg} \cdot \mathrm{kg}^{-1}$ of imidacloprid. However, after 14 days of using, the doses of $0.66 \mathrm{mg} \cdot \mathrm{kg}^{-1}$ and $2 \mathrm{mg} \cdot \mathrm{kg}^{-1}$ caused $100 \%$ mortality of the studied E. fetida specimens. A decrease in body weight of E. fetida or E. andrei earthworms in response to imidacloprid was also confirmed by Fernández-Gómez et al. (2009) and Alves et al. (2013).

The present study indicates the toxicity of $\mathrm{Nu}-$ prid 200SC at the dose recommended by the manufacturer as environmentally safe. Since, the applied agent had the effect on a decrease in the mean individual body weight and the mean sum of biomass of $D$. veneta from all the age groups.

It is worth to mention the other neonicotinoid insecticide-paichongding (IPP) that is widely used in China. Zhang et al. (2017) investigated the effect of IPP on acute toxicity in E. fetida in filter paper contact test and artificial soil test. LC50 concentrations were determined in both experiments. In filter paper contact test, the concentration amounted to $14.98 \mu \mathrm{g} \cdot \mathrm{cm}^{-2}$ (after 24 hours) and $7.59 \mu \mathrm{g}$. $\mathrm{cm}^{-2}$ (after 48 hours). In turn, in artificial soil test, the LC50 value for IPP amounted to $541.07 \mathrm{mg}$. $\mathrm{kg}^{-1}$ (after 14 days) and $238.51 \mathrm{mg} \cdot \mathrm{kg}^{-1}$ (after 28 days). LC50 determined in both tests for $E$. fetida as a response to IPP is considerably higher than in case of traditional neonicotinoid insecticides. The assessment of earthworm body weight demonstrated that earthworm growth was inhibited by the prolonged exposure to IPP in the artificial soil test.

A similar relation was observed for the new cis configuration neonicotinoid insecticide called Cycloxaprid (CYC). It demonstrates high activity 
against pests resistant to imidacloprid. Suzhen et al. (2018) studied acute toxicity of this compound to E. fetida in the artificial soil test. A negative effect on earthworms was demonstrated both under the conditions of acute and long-term exposure, however, the toxicity of this compound was lower, similar as in case of IPP, compared to the traditional neonicotinoids. In the study described in the present paper, imidacloprid disturbed the reproduction of $D$. veneta, which was manifested by a significant reduction in the number of laid cocoons, so the studied population did not develop. A similar effect was demonstrated by Wang et al. (2015a), who investigated the effect of neonicotinoids: imidacloprid, clothianidin, nitenpyram, thiacloprid and acetamiprid in relation to the mature E. fetida specimens in the artificial soil test. All the applied measures restricted the number and weight of cocoons and the number of earthworms hatched from one cocoon. Among the studied compounds, clothianidin was the most toxic - already at the dose of $4.34 \mathrm{mg} \cdot \mathrm{kg}^{-1}$. In the studies carried out by Zang et al. (2000) it was demonstrated that imidacloprid may damage DNA and causes sperm deformity in E. fetida (starting from the concentration of $\left.0.5 \mathrm{mg} \cdot \mathrm{kg}^{-1}\right)(\mathrm{p}<0.01)$.

All the mentioned facts indicate that it is necessary to apply neonicotinoids very carefully and the usage of these insecticides should be restricted. In order to assess the actual risk of neonicotinoids for the biodiversity and ecosystems, it is also necessary to obtain the overall image of their distribution and transfer in the environment.

\section{CONCLUSIONS}

1. Results of the conducted studies with the use of concentration of $0.4 \mathrm{ml} \cdot \mathrm{m}^{-2}$, corresponding to the safe dose according to the manufacturer, indicate high toxicity of imidacloprid (trade name Nuprid 200SC) towards D. veneta.

2. Under the conditions applied in the present experiment, the studied insecticide:

- decreased the number of the entire population $(p<0.01)$, the number of mature specimens $(p<0.0001)$ and immature specimens $(p<0.001)$. It also reduced the reproduction - by decreasing the number of laid cocoons ( $\mathrm{p}<0.01$ ),

- reduced the biomass of the population $(\mathrm{p}<0.0001)$, weight of an individual specimen in the entire population $(p<0.05)$; the insecticide also disturbed biomass growth in mature specimens $(p<0.0001)$ and the weight growth of the individual specimens $(p<0.01)$. Similar situation was observed in immature specimens $(\mathrm{p}<0.01)$ and in biomass of cocoons in D. veneta $(\mathrm{p}<0.05)$.

3 . The studies indicate that there is a need for further studies on the effect of neonicotynoids on earthworms as well as on the other organisms.

\section{REFERENCES}

1. Alves P.R.L., Cardoso E.J.B.N., Martines A.M., Sousa J.P., Pasini A. 2013. Earthworm ecotoxicological assessments of pesticides used to treat seeds under tropical condition. Chemosphere, 90(11), 2674-2682. https://doi.org/10.1016/j.chemosphere.2012.11.046

2. Basley K., Goulson D. 2017. Effects of chronic exposure to clothianidin on the earthworm Lumbricus terrestris. PeerJ, April 11, https:// doi:org/ 10.1016/j.chemosphere.2012.11.046

3. Bonmatin J.M., Giorio C., Girolami V., Goulson D., Kreutzweiser D., Krupke C., Liess M., Long E., Marzaro M., Mitchell E., Noome D., Simon-Delso N., Tapparo A. 2014. Environmental fate and exposure; neonicotinoids and fipronil. Environmental Science and Pollution Research, 22(1), 35-67. https://doi:org/ 10.1007/s11356-014-3332-7.

4. Botías C., David A., Hill E.M., Goulson D. 2016. Contamination of wild plants near neonicotinoid seedtreated crops, and implications for non-target insects. Science of the Total Environment, 566-567, 269-278. https://doi:org/ 10.1016/j.scitotenv.2016.05.065.

5. Chen Ch., Wang Y., Zhao X., Wang Q., Qian Y. 2014. Comparative and combined acute toxicity of butachlor, imidacloprid and chlorpyrifos on earthworm, Eisenia fetida. Chemosphere, 100, 111-115. https://doi.org/10.1016/j.chemosphere.2013.12.023.

6. Dittbrenner N., Schmitt H., Capowicz Y., Triebskorn R. 2011. Sensitivity of Eisenia fetida in comparison to Aporrectodea caliginosa and Lumbricus terrestris after imidacloprid exposure. Body mass change and histopathology. Journal of Soils and Sediments, 11(6), 1000-1010. https://doi:org/: $10.1007 / \mathrm{s} 11368-011-0397-5$.

7. Eng M., Stutchbury B.J., Morrissey C.A. 2017. Imidacloprid and chlopyrifos impair migratory ability in a seed-eating songbird. Scientific Reports, 7,151-176. https://doi:org/:10.1038/ s41598-017-15446-x.

8. Garczyńska M., Pączka G., Mazur-Pączka A., Kostecka J. 2018. Earthworms in short-term contact with a low dose of neonicotinoid Actara 25WG. Journal of Ecological Engineering, 19(3), 93-101. https://doi.org/10.12911/22998993/86254.

9. Gomez-Eyles J.L., Svendsen C., Lister L., Martin H., Hodson M.E., Spurgeon D. 2009. Mea- 
suring and modelling mixture toxicity of imidacloprid and thiacloprid on Caenorhabditis elegans and Eisenia fetida. Ecotoxicology and Environmental Safety, 72, 71-79. https://doi.org /10.1016/j.ecoenv.2008.07.006.

10. Hladik M.L., Anson R., Main A.R.M., Goulson D. 2018. Environmental risks and challenges associated with neonicotinoid insecticides. Environmental Science and Technology, 52, 3329-3335. https:// doi.org/10.1021/acs.est.7b06388.

11. Johnston A.S.A., Hodson M.E., Thorbek P., Alvarez T., Sibly R.M. 2014. An energy budżet agent-based model of earthworm populations and its applications to study the effects of pesticides. Ecological Modelling, 280, 5-17. https://doi.org/10.1016/j. ecolmodel.2013.09.012.

12. Kostecka J. 2000. Investigation into vermicomposting of organic wastes. Scient Paper of Agricultular University of Cracow, 268, pp. 88 (in Polish).

13. Lukkari T., Aatsinki M., Vaisanen A., Haimi J. 2005. Toxicity of copper and zinc assessed with three different earthworm tests. Applied Soil Ecology, 30, 133-146. https://doi.org/10.1016/j.apsoil.2005.02.001.

14. Mörtl M., Kereki O., Darvas B., Klatyik Sz., Vehovszky A., Györi J., Szekacs A. 2016. Study on soli mobility of two neonicotinoid insecticides. Journal of Chemistry. ID 4546584: 9 http:/dx.doi. org/10.1155/2016/4546584.

15. OECD 2004. Test 222: Earthworm Reproduction Test (Eisenia fetida/Eisenia andrei), OECD Guidelines for the Testing of Chemicals, Section 2, OECD Publishing, Paris. http://dx.doi. org/10.1787/9789264070325-en.

16. Olvera-Velona A., Capowiez Y., Mascle O., OrtizHernandez L., Benoit P. 2008. Assessment of the toxicity of ethyl-parathion to earthworms (Aporrectodea caliginosa) using behavioural, physiological and biochemical markers. Applied Soil Ecology, 40(3), 476-483. https://doi.org/ 10.1016/j. apsoil.2008.07.002.

17. Pelosi C., Bertrand M., Capowiez Y., Boizard H., Roger-Estrade J. 2009. Earthworm collection from agricultural fields: comparisons of selected expellants in presence/absence of hand-sorting. European Journal of Soil Biology, 45, 176-183. https:// doi.org/10.1016/j.ejsobi.2008.09.013.

18. Podolak-Machowska A. 2016. Reactions earthworms (Lumbricidae) to stress on the population and cell level. PhD thesis. Faculty of Biology of Agriculture. University of Rzeszow. http://repozytorium.ur.edu.pl/handle/item/2295.

19. Raymann K., Motta E.V.S., Girard C., Raddington I.M., Dinser J.A., Morgan N.A. 2018. Imidacloprid decreases honey bee survival rates but does not affect the gut microbiome. Applied Environmental Microbiology, 84(13). https://doi.org/ 10.1128/ AEM.00545-18.
20. Renaud M., Akeju T., Natal-da-Luz T., Leston S., Rosa J., Ramos F., Jose Paulo Sousa J., Azevedo-Pereira H. M.V.S. 2018. Effects of the neonicotinoids acetamiprid and thiacloprid in their commercial formulations on soil fauna. Chemosphere, 194, 85-93. https://doi.org/10.1016/j.chemosphere.2017.11.102.

21. Stanisz A. 2006. An affordable statistic course using Statistica PL on examples of medicine (in Polish). StatSoft Polska Sp. z o.o. Cracow, pp. 532.

22. Suchail S., Debrauwer L.; Belzunces L.P. 2004. Metabolism of imidacloprid in Apis mellifera. Pest Manage Sci., 60(3), 291-296. https://doi. org/10.1002/ps.772.

23. Suzhen QI., Donghui W., Lizhen Zh., Miaomiao T., Chengju W., Xiaofeng X., Liming W. 2018. Effects of a novel neonicotinoid insecticide cycloxaprid on earthworm, Eisenia fetida. Environmental Science and Pollution Research, 25(14), 14138-14147. https://doi.org/10.1007/s11356-018-1624-z.

24. Uhl P., Bucher R., Schafer R.S., Entling M.H 2015. Sublethal effects of imidacloprid on interactions in a tritrophic system on non target species. Chemosphere, 132, 152-158. https://doi.org/10.1016/j. chemosphere.2015.03.027.

25. Wang K., Pang S., Mu X., Qi S., Li D., Cui F., Wang C. 2015a. Biological response of earthworm, Eisenia fetida, to five neonicotinoid insecticides. Chemosphere, 132, 120-126. 10.1016/j.chemosphere.2015.03.002.

26. Wang K., Suzhen Qi., Xiyan M., Tingling Ch., Yang Y., Danden W., Dongzhai Li., Wunam Ch., Chengju W. 2015b. Evaluation of te toxicity, Ache activity and DNA damage cause by imidachloprid of earthworms, Eisenia fetida. Bulletin of Environmental Contamination Toxicology, 95, 475-480. https://doi.org/10.1007/S00128-015-1629-y.

27. Wood T.J., Goulson D. 2017. The environmental risks of neonicotinoid pesticides: a review of the evidence post 2013. Environmental Science and Pollution Research, 24, 17285-17325. https://doi. org/10.1007/s 11356-017-9240-X.

28. Zang Y., Zhong Y., Luo Y., Kong Z.M. 2000. Genotoxicity of two novel pesticides for the earthworm, Eisenia fetida. Environmental Pollution, 108(2), 271-278. https://doi.org/10.1016/ S0269-7491(99)00191-8.

29. Zhang J., Xiong K., Chen A., Li T. 2017. Toxicity a novel neonicotinoid insecticide paichongding to earthworm Eisenia fetida. Soil Sediment and Contamination, 26(3), 235-246. https:// doi.org/10.1080. ttps://doi.org/10.1080/15320383.2017.1276153

30.Zhang Q., Zhang B., Wang C. 2014. Ecotoxicological effects on the earthworm Eisenia fetida following exposure to soil contaminated with imidacloprid. Environmental Science Pollution Research International 21(21), 12345-53. https://doi. org/10.1007/s11356-014-3178-z. 